\title{
FAKTOR DETEKSI DINI KANKER SERVIKS METODE IVA PADA WANITA USIA SUBUR
}

\author{
Nur Asni Arti \\ Departemen Kesehatan Reproduksi, Fakultas Kesehatan Masyarakat \\ Universitas Sumatera Utara, Medan, 20155, Indonesia \\ E-mail: bonjol.101_pb@yahoo.co.id
}

Diterima: April 2017, diterbitkan: Agustus 2017

\begin{abstract}
ABSTRAK
Meningkatnya kejadian kanker serviks terutama disebabkan masih rendahnya perilaku wanita usia subur (WUS) untuk deteksi dini kanker serviks. Salah satu upaya pemerintah untuk mendeteksi kanker serviks secara dini adalah melalui metode inspeksi visual asam asetat (IVA). Cakupan IVA di Desa Payageli sangat rendah sebesar 2,8\%, masih di bawah target nasional (80\%). Tujuan penelitian: Menganalisis hubungan pendidikan dan pengetahuan dengan deteksi dini kanker serviks metode IVA pada WUS di Desa Payageli, Kecamatan Sunggal, Kabupaten Deli Serdang. Metode: Penelitian ini merupakan studi analitik dengan metode potong lintang yang dilaksanakan dari bulan Februari sampai Juni 2016. Cara pemilihan sampel ialah probability sampling dengan jumlah sampel sebanyak 65 orang wanita usia 20-45 tahun. Pengumpulan data menggunakan kuesioner yang disusun oleh peneliti dan telah diuji validitas dan reliabilitasnya. Data dianalisis dengan uji chi square. Hasil: Penelitian menunjukkan bahwa secara statistik faktor pendidikan dan pengetahuan berhubungan dengan deteksi dini kanker serviks metode IVA dengan nilai $\overline{\mathrm{p}} 0,05$. Variabel pendidikan merupakan variabel yang paling dominan berhubungan dengan deteksi dini kanker serviks metode IVA. Diskusi: Rendahnya pengetahuan dapat memengaruhi WUS untuk melakukan deteksi dini kanker serviks. Kesimpulan: Peran petugas kesehatan untuk lebih aktif melakukan penyuluhan atau memberikan KIE (komunikasi, informasi, edukasi) kepada WUS tentang deteksi dini kanker serviks dengan metode IVA.
\end{abstract}

Kata Kunci: IVA, kanker serviks, deteksi dini

\section{FACTORS RELATED TO EARLY DETECTION OF CERVICAL CANCER USING IVA METHOD AY PAYAGELI VILLAGE, SUNGGAL, DELI SERDANG ABSTRACT}

The increasing incidence of cervical cancer is primarily caused by low behavior of women of reproductive age towards early detection of cervical cancer. One of the government's efforts to detect cervical cancer early is through a visual inspection with acetic acid (VIA) method. The coverage of VIA at Payageli Village is very low by 2.8\%, which is below the national target of $80 \%$. Objective: To analyze the correlation of education and knowledge with early detection of cervical cancer using VIA method in women of reproductive age in Payageli Village, Sunggal Subdistrict, Deli Serdang Regency. Methods: This research is an analytic study using a cross sectional method which was conducted from February to June 2016. Samples were taken using probability sampling with a sample size of 65 women aged 20-45 years. Data were collected through in-depth interviews using questionnaires that was made by the researcher and its validity and reliability had been tested. Data was analyzed using chi square test. Results: The research indicated that statistically the factors of education and knowledge correlated with early detection of cervical cancer using VIA method with $p$ value of $<0.05$. the education variable was the most dominant variables correlated with early detection of cervical cancer using VIA method. Discussion: Poor knowledge may affect women of reproductive age to perform early detection of cervical cancer. Conclusion: Healthcare workers should play more active role in giving counseling or providing communication, information and education to women of reproductive age about early detection of cervical cancer by using VIA method. Keywords: VIA, cervical cancer, early detection 


\section{PENDAHULUAN}

Sampai saat ini penyakit kanker serviks masih menjadi masalah kesehatan di dunia, terutama di negara berkembang. Besarnya masalah tersebut terlihat dari masih tingginya angka kesakitan dan kematian akibat penyakit kanker serviks. Berdasarkan data WHO (World Health Organization), terdapat 493.243 per tahun penderita kanker serviks baru di dunia dengan angka kematian sebanyak 273.505 jiwa per tahun. Di Indonesia, terjadi 15.000 kasus baru kanker serviks dengan angka kematian sebanyak 7.500 kasus per tahun (Emilia et al., 2014). Data tersebut menunjukkan bahwa setiap 30 menit wanita terkena kanker dan setiap 1 jam wanita meninggal akibat kanker (Pudiastuti, 2011).

Estimasi Globocan, International Agency for Research on Cancer (IARC) tahun 2012, insiden kanker di Indonesia 134 per 100.000 penduduk dengan insiden tertinggi pada wanita ialah kanker payudara sebesar 40 per 100.000 diikuti kanker serviks sebesar 17 per 100.000 dan kanker kolorektal 10 per 100.000 wanita (Kementerian Kesehatan R. I, 2015b). Prevalensi penderita kanker serviks menurut Provinsi Sumatera Utara Tahun 2013 sebesar 0,7 per 1.000 penduduk atau sebanyak 4.694 orang. Berdasarkan Riset Kesehatan Dasar tahu 2013, secara nasional, prevalensi tertinggi kanker serviks sebesar 0,8 per 1.000 penduduk atau sekitar 98.692 orang (Kementerian Kesehatan R.I, 2013). Untuk daerah Deli Serdang, berdasarkan data dari RSU Deli Serdang, tahun 2015 jumlah penderita kanker serviks sebanyak 40 orang dengan kondisi 12 orang rawat inap dan 28 orang rawat jalan.

Kanker serviks adalah tumor ganas yang tumbuh di dalam serviks atau leher rahim yang biasanya berkembang secara bertahap, tetapi cukup progresif. Penyebab kelainan secara pasti belum diketahui, tetapi terdapat beberapa faktor risiko yang berpengaruh antara lain HPV (human papilloma virus), merokok, hubungan seksual pertama dilakukan pada usia dini, bergantiganti pasangan seksual, gangguan sistem kekebalan tubuh, pemakaian pil Keluarga Berencana (KB), serta infeksi genitalis atau infeksi klamidia menahun (Nugroho \& Utama, 2014; Saydam, 2012; Pudiastuti, 2011).

Berdasarkan peraturan pemerintah, upaya penanggulangan kanker serviks salah satunya dalam bentuk pelayanan preventif melalui kegiatan skrining massal/deteksi dini oleh dokter atau bidan terlatih di fasilitas kesehatan (Kementerian Kesehatan R.I, 2015c).

Masalah yang mengadang dalam penanggulangan kanker serviks ialah masih rendahnya angka cakupan deteksi dini atau skrining kanker. Berdasarkan kegiatan dari tahun 2007-2014 pada 904.099 orang (2,45\%) dengan hasil IVA positif sebanyak 44.654 orang (4,94\%), suspek kanker leher rahim sebanyak 1.056 orang (1,2 per 1.000 orang). Terlihat bahwa cakupan dari skrining kanker serviks masih sedikit sehingga kegiatan deteksi dini perlu terus diperkuat di daerah yang sudah mengembangkan dan diperluas ke daerah lain yang belum mengembangkan program tersebut (Kementerian Kesehatan R. I, 2015a).

Tujuan penelitian ialah untuk menganalisis faktor-faktor yang berhubungan dengan deteksi dini kanker serviks metode IVA pada wanita usia subur (WUS) di Desa Payageli, Kecamatan Sunggal, Kabupaten Deli Serdang.

\section{METODE}

Jenis penelitian ini merupakan penelitian kuantitatif dengan pengumpulan data melalui metode wawancara berdasarkan kuesioner dengan bentuk pertanyaan terbuka dan tertutup berupa pilihan ganda yang disusun 
sendiri oleh peneliti sesuai dengan masalah serta tujuan penelitian berdasarkan rujukan dari Emilia et al. (2014). Selanjutnya, dilakukan uji validitas dan uji reliabilitas pada 30 WUS pada desa lain di Deli Serdang dengan karakteristik sama. Pertanyaan berjumlah 20 item tentang pengetahuan menunjukkan nilai corrected item total correlation $(r)>0,361$ (r-tabel) dengan nilai Cronbach's alpha $0,949>0,60$. Dapat disimpulkan bahwa 20 pertanyaan pengetahuan valid dan reliabel sebagai alat ukur.

Populasi pada penelitian ini, seluruh WUS di Desa Payageli Kecamatan Sunggal Kabupaten Deli Serdang yang berjumlah 3.529 orang. Pengambilan sampel melalui teknik probability, yakni memberikan peluang atau kesempatan yang sama bagi setiap individu atau objek pada suatu populasi sebagai sampel penelitian dengan metode simple random sampling dengan menyiapkan daftar komplet populasi (sampling frame) dari kelurahan, sampai memenuhi besar sampel yang diinginkan yakni sebanyak 65 orang. Jumlah sampel (ukuran sampel) dalam penelitian ini ditentukan dengan menggunakan rumus yang dikembangkan oleh Lemeshow (1990/1997).

Metode pengukuran menggunakan skala Likert. Chandra (2013) menyatakan bahwa jika responden menjawab benar, diberi nilai 1 , menjawab salah diberi nilai 0 . Maka, skor tertinggi adalah $1 \times 20=20$, kemudian diakumulasi dan dikelompokkan dalam kategori: a. kurang, jika responden memperoleh nilai $\leq 50 \%(0-10)$ dan b. baik, jika responden memperoleh nilai $>50 \%$ (11-20). Analisis data dalam penelitian ini meliputi: a. analisis univariat, bertujuan untuk melihat gambaran distribusi frekuensi dan persentase yang diteliti dari variabel independen (pendidikan dan pengetahuan) dengan variabel dependen (deteksi dini kanker serviks metode IVA), b. analisis bivariat dilakukan untuk mengidentifikasi hubungan variabel independen (pendidikan dan pengetahuan) dengan variabel dependen (deteksi dini kanker serviks metode IVA).

Hasil analisis dikatakan ada hubungan yang signifikan antara variabel independen dan variabel dependen menggunakan uji chisquare jika pada tingkat kemaknaan $\alpha<0,05$ dan tidak ada hubungan jika pada tingkat kemaknaan $\alpha>0,05$.

Pertimbangan etik dalam penelitian ini, diawali dengan pengurusan ijin pada pihak pemerintah desa Payageli untuk memperoleh dukungan dan ijin untuk melakukan penelitian. Selanjutnya pendekatan pada responden sesuai jumlah sampel yang ditentukan. Peneliti terlebih dahulu memperkenalkan diri, memberi penjelasan tentang tujuan penelitian. Responden yang bersedia diminta menandatangani lembar persetujuan dan kerahasiaan informasi dijaga dengan hanya menuliskan inisial nama responden.

\section{HASIL PENELITIAN}

Responden dalam penelitian ini adalah WUS sebanyak 65 orang. Karakteristik responden yang dilihat meliputi umur, pendidikan, dan pekerjaan. Penelitian menunjukkan bahwa jumlah umur paling banyak yakni 41 orang $(63,1 \%)$ berada pada usia $\geq 30$ tahun. Berdasarkan pendidikan, jumlah tertinggi dengan pendidikan rendah (SD dan SMP) sebanyak 36 orang $(55,4 \%)$ Berdasarkan pekerjaan, umumnya responden tidak bekerja, yakni sebanyak 40 orang $(61,5 \%)$. Hal ini dapat dilihat pada Tabel 1 berikut ini. 
Tabel 1. Distribusi frekuensi karakteristik responden di Desa Payageli, Kecamatan Sunggal, Kabupaten Deli Serdang

\begin{tabular}{|c|c|c|c|}
\hline No. & Karakteristik & $\mathbf{n}$ & $\%$ \\
\hline & Umur & & \\
\hline & $<30$ tahun & 24 & 36,9 \\
\hline & $\geq 30$ tahun & 41 & 63,1 \\
\hline & Pendidikan & & \\
\hline & Rendah (SD dan & 36 & 55,4 \\
\hline & SMP) & & \\
\hline & Tinggi (SMA dan & 29 & 44,6 \\
\hline & PT) & & \\
\hline 3. & Pekerjaan & & \\
\hline & Tidak Bekerja & 40 & 61,5 \\
\hline & Bekerja & 25 & 38,5 \\
\hline
\end{tabular}

Pengetahuan responden tentang kanker sebagai deteksi dini kanker serviks. Variabel serviks meliputi semua pengetahuan tentang pengetahuan responden dapat dilihat pada pengertian, tanda dan gejala serta metode IVA tabel 2 berikut ini.

Tabel 2. Distribusi frekuensi pengetahuan responden di Desa Payageli, Kecamatan Sunggal, Kabupaten Deli Serdang

\begin{tabular}{llcc}
\hline No. & Pengetahuan & $\mathbf{n}$ & $\mathbf{\%}$ \\
\hline Kurang & 49 & 75,4 \\
Baik & 16 & 24,6 \\
\hline
\end{tabular}

Berdasarkan Tabel 2 diketahui bahwa Untuk mengetahui gambaran responden paling banyak memiliki tingkat keikutsertaan responden melakukan deteksi pengetahuan yang kurang, yakni sebesar 49 dini kanker serviks metode IVA dapat dilihat orang $(75,4 \%)$. pada tabel 3 berikut ini.

Tabel 3. Distribusi frekuensi responden melakukan deteksi dini kanker serviks metode IVA di Desa Payageli, Kecamatan Sunggal, Kabupaten Deli Serdang

\begin{tabular}{llcc}
\hline No. & Pemeriksaan IVA & $\mathbf{n}$ & $\mathbf{\%}$ \\
\hline 1. & Pernah & 28 & 43,1 \\
2. & Tidak Pernah & 37 & 56,9 \\
\hline
\end{tabular}

Berdasarkan Tabel 3 dapat dilihat bahwa variabel independen (pendidikan dan dari 65 orang responden lebih banyak yang pengetahuan) dengan variabel dependen tidak pernah melakukan pemeriksaan IVA (deteksi dini kanker serviks metode IVA). yakni sebanyak 37 orang $(56,9 \%)$. Hubungan variabel pendidikan dengan

Selanjutnya dari hasil di atas dilakukan deteksi dini kanker serviks metode IVA dapat analisis untuk mencari hubungan antara dilihat pada tabel 4 berikut ini. 
Tabel 4. Hubungan pendidikan dengan deteksi dini kanker serviks metode IVA di Desa Payageli, Kecamatan Sunggal, Kabupaten Deli Serdang

\begin{tabular}{|c|c|c|c|c|c|}
\hline \multirow{3}{*}{ Pendidikan } & \multicolumn{4}{|c|}{$\begin{array}{l}\text { Deteksi Dini } \\
\text { Metode IVA }\end{array}$} & \multirow{3}{*}{ p-value } \\
\hline & \multicolumn{2}{|c|}{ Pernah } & \multicolumn{2}{|c|}{$\begin{array}{l}\text { Tidak } \\
\text { Pernah }\end{array}$} & \\
\hline & $\mathbf{F}$ & $\%$ & $F$ & $\%$ & \\
\hline Tinggi & 18 & 62,1 & 11 & 37,9 & 0,000 \\
\hline Rendah & 6 & 16,7 & 30 & 83,3 & \\
\hline Total & 24 & 36,9 & 41 & 63,1 & \\
\hline
\end{tabular}

Berdasarkan Tabel 4 dapat diketahui bahwa dari 36 orang wanita PUS dengan kategori pendidikan rendah (SD dan SMP) ada sebanyak 30 orang $(83,3 \%)$ tidak melakukan deteksi dini kanker serviks melalui metode IVA dan yang melakukan sebanyak 6 orang $(16,7 \%)$. Untuk kategori pendidikan tinggi (SMP dan SMA), dari 29 orang, yang melakukan deteksi dini kanker serviks melalui metode IVA sebanyak 18 orang $(62,1 \%)$ dan tidak melakukan sebanyak 11 orang $(37,9 \%)$.

Ada kecenderungan responden dengan pendidikan rendah hanya sedikit melakukan deteksi dini kanker serviks. Hasil uji statistik menunjukkan bahwa ada hubungan yang signifikan antara pendidikan dan deteksi dini kanker serviks melalui metode IVA dengan nilai $p=0,000(p<0,05)$.

Hubungan variabel pengetahuan dengan deteksi dini kanker serviks metode IVA dapat dilihat pada tabel 5 berikut ini.

Tabel 5. Hubungan pengetahuan dengan deteksi dini kanker serviks metode IVA di Desa Payageli, Kecamatan Sunggal, Kabupaten Deli Serdang

\begin{tabular}{lrrrrr}
\hline \multirow{3}{*}{ Pengetahuan } & \multicolumn{4}{c}{$\begin{array}{c}\text { Deteksi Dini } \\
\text { Metode IVA }\end{array}$} & p-value \\
\cline { 2 - 5 } & \multicolumn{4}{c}{ Pernah } & \multicolumn{3}{c}{ Tidak Pernah } & \\
\cline { 2 - 5 } & $\mathbf{F}$ & $\%$ & $\mathbf{F}$ & $\%$ & \\
\hline Kurang & 13 & 26,5 & 36 & 73,5 \\
\hline Baik & 15 & 93,8 & 1 & 6,023 \\
\hline Total & 28 & 43,1 & 37 & 56,9 \\
\hline
\end{tabular}

Berdasarkan Tabel 5 dapat diketahui bahwa dari 49 orang wanita PUS yang memiliki pengetahuan kurang, ada sebanyak 36 orang $(73,5 \%)$ yang tidak melakukan deteksi dini kanker serviks melalui metode IVA dan yang melakukan sebanyak 13 orang $(26,5 \%)$. Dari 16 orang wanita PUS dengan pengetahuan baik, yang melakukan deteksi dini kanker serviks melalui metode IVA sebanyak 15 orang $(93,8 \%)$ dan yang tidak melakukan sebanyak 1 orang $(6,2 \%)$. Ada kecenderungan responden dengan pengetahuan kurang, lebih banyak tidak melakukan deteksi dini kanker serviks. Hasil uji statistik menunjukkan ada hubungan yang signifikan antara pengetahuan dan deteksi dini kanker serviks melalui metode IVA dengan nilai $p=0,023(p<0,05)$.

\section{PEMBAHASAN}

Berdasarkan hasil penelitian menunjukkan bahwa responden yang melakukan deteksi dini kanker serviks metode IVA umumnya dengan tingkat pendidikan tinggi (SMA dan PT). Hal ini sejalan dengan hasil penelitian Mirayashi, Raharjo, \& Wicaksono (2014) pada wanita yang melakukan pemeriksaan IVA di Puskesmas Alianyang, Pontianak yang menunjukkan bahwa karakteristik ibu yang melakukan deteksi dini kanker serviks 
umumnya tingkat pendidikan tinggi, yakni lulusan SMA sebesar 28 orang $(31,8 \%)$ dan sebanyak 10 orang $(11,4 \%)$ merupakan lulusan perguruan tinggi, sedangkan 3 orang $(3,4 \%)$ merupakan lulusan SD. Hasil uji statistik sama-sama menunjukkan adanya hubungan yang signifikan, yakni sebesar $p=0,000$.

Penelitian ini menunjukkan bahwa meningkatnya pendidikan seseorang akan membuat orang tersebut semakin peduli terhadap kesehatannya. Pendidikan yang dijalani seseorang memiliki pengaruh pada peningkatan kemampuan berpikir, seseorang yang berpendidikan lebih tinggi akan dapat mengambil keputusan yang lebih rasional, umumnya terbuka untuk menerima perubahan atau hal baru dibanding individu yang berpendidikan lebih rendah. Pendidikan memberi efek positif pada kesadaran kesehatan dan secara langsung memengaruhi perilaku kesehatan (Notoatmodjo, 2012).

Seseorang dengan pendidikan yang tinggi, akan mudah menerima informasiinformasi kesehatan dari berbagai media dan biasanya ingin selalu berusaha mencari informasi tentang hal-hal yang berhubungan dengan kesehatan yang belum diketahuinya, informasi yang cukup terutama pada WUS mengenai IVA diharapkan akan dapat merubah pola perilaku hidup sehat.

Pada penelitian ini diketahui bahwa responden yang banyak tidak melakukan deteksi dini kanker serviks metode IVA umumnya dengan pengetahuan kurang baik. Hal ini sejalan dengan hasil penelitian yang dilakukan oleh Basu et al. (2014) terhadap wanita di Maldives serta Jia et al. (2013) pada wanita di Kota Wufeng, Cina yang menyatakan ada hubungan yang bermakna antara pengetahuan dan perilaku pemeriksaan deteksi dini kanker serviks metode IVA dengan nilai $p=0,000$. Selain itu, penelitian yang dilakukan oleh Reis et al. (2012) menunjukkan hasil pengetahuan wanita Turki berpengaruh terhadap deteksi dini kanker serviks dengan $p=0,001$.

Pengetahuan terbentuk setelah seseorang menerima informasi. Perilaku sehat seperti melakukan upaya deteksi dini kanker serviks memerlukan pengetahuan dan kesadaran individu. Dengan adanya pengetahuan yang baik, seseorang akan mencari informasi tentang kesehatannya. Semakin banyak seseorang memperoleh pengetahuan tentang kanker serviks, semakin besar kemungkinan untuk melakukan deteksi dini kanker serviks metode IVA. Kesadaran dan kepedulian WUS meningkat terhadap keadaan kesehatan dirinya, terutama kesehatan reproduksinya. Pengetahuan dikatakan sebagai alat yang dapat digunakan untuk memecahkan masalah yang dihadapi manusia. Sehingga melalui pengetahuan yang didapat, orang akan mencari alat untuk memecahkan masalahnya, terkait dengan kanker serviks maka orang akan mencari tahu tentang penyebab, cara penularan, pencegahan, maupun cara mendeteksinya, selanjutnya akan melakukan pemeriksaan IVA secara rutin dan tepat waktu, sebagai bentuk pemecahan masalah tersebut.

Berdasarkan penelitian, keikutsertaan 28 orang responden dalam melakukan deteksi dini kanker serviks setelah diberitahu oleh petugas Puskesmas Muliorejo saat berobat serta diajak teman. Deteksi dini kanker serviks dengan metode IVA yang responden lakukan tidak ada yang berlanjut, hanya saat itu saja. Tindakan deteksi dini yang dilakukan responden tersebut menurut Notoatmodjo (2012) bersifat sementara dan tidaklah lama karena perubahan perilaku yang tidak didasari oleh pengetahuan dan kesadaran yang tinggi tidaklah langgeng.

Penelitian ini hanya melihat hubungan faktor pendidikan dan pengetahuan responden terhadap deteksi dini kanker 
serviks metode IVA, tapi tidak menganalisis faktor yang memotivasi responden tersebut secara lebih dalam. Hal ini perlu dilakukan penelitian lebih lanjut agar mendapatkan masalah yang lebih jelas yang menghambat dalam penanggulangan kanker serviks selanjutnya.

\section{SIMPULAN}

Berdasarkan hasil penelitian dan pembahasan didapatkan bahwa tingkat pendidikan dan pengetahuan wanita PUS tentang kanker serviks mempunyai hubungan dengan deteksi dini kanker serviks metode IVA. Untuk itu, pemberian penyuluhan/ pendidikan kesehatan terutama tentang kesehatan reproduksi WUS dan kanker serviks dapat dilakukan secara berkesinambungan sehingga dapat meningkatkan pengetahuan serta kesadaran masyarakat, terutama WUS untuk mau melakukan deteksi dini kanker serviks metode IVA.

\section{DAFTAR PUSTAKA}

Basu, P., Hassan, S., Fileeshia, F., Mohamed, S., Nahoodha, A., Shiuna, A., Sulaiman, A. I., ..., Saleem, F. J. (2014). Knowledge of women in Maldives related to the risk factors, prevention and early detection of cervical cancer. Asian Pac J Cancer Prev, 15(16): 6691-6695.

Chandra, B. (2013). Metodologi penelitian kesehatan. Jakarta: EGC.

Emilia, O., Kusumanto, D., Hananta, I. P. Y., \& Freitag, H. (2014). Bebas ancaman kanker serviks (Cetakan 1). Yogyakarta: Media Pressindo.

Jia, Y., Li, S., Yang, R., Zhou, H., Xiang, Q. $\mathrm{Hu}, \mathrm{T}$., Zhang, Q., ..., Feng, L. (2013). Knowledge about cervical cancer and barriers of screening program among women in Wufeng country, a highincidence region of cervical cancer in China. PLoS One, 8(7): e67005
Kementerian Kesehatan R. I. (2013). Riset kesehatan dasar nasional. Jakarta: Badan Penelitian dan Pengembangan Kesehatan.

Kementerian Kesehatan Republik Indonesia (2015a). Buletin jendela data dan informasi kesehatan September 2015. http://www.depkes.go.id/folder/view/01/ structure-publikasi-data-pusat-datadan-informasi.html.

Kementerian Kesehatan Republik Indonesia (2015b). Panduan program nasional gerakan pencegahan dan deteksi dini kanker leher rahim dan kanker payudara 21 April 2015. Retrieved from http:// www.p2ptm.kemkes.go.id/dokumenp2ptm/panduan-program-nasionalgerakan-pencegahan-dan-deteksi-dinikanker-kanker-leher-rahim-dan-kankerpayudara-21-april-2015

Kementerian Kesehatan Republik Indonesia (2015c). Peraturan Menteri Kesehatan Republik Indonesia Nomor 34 Tahun 2015, penanggulangan kanker payudara dan kanker leher rahim. http://www.hukor. kemkes.go.id/uploads/produk_hukum/ PMK_No.34_ttg_Penanggulangan_ Kanker_Payudara_dan_Leher_Rahim_. pdf.

Lemeshow, S., David, W. J. H., Jenelle, K., \& Stephen, K. L. (1997). Sample size in health studies. (Alih bahasa: Pramono, Dibyo \& Hari Kusnanto). Yogyakarta: Gadjah Mada University Press. (Buku asli diterbitkan 1990).

Mirayashi, D., Raharjo, W., \& Wicaksono, A. (2014). Hubungan antara tingkat pengetahuan tentang kanker serviks dan keikutsertaan melakukan pemeriksaan inspeksi visual asetat di Puskesmas Alianyang Pontianak. Jurnal Mahasiswa PSPD FK Universitas Tanjungpura, 1(1): 1-18.

Notoatmodjo, S. (2012). Promosi kesehatan 
dan perilaku kesehatan (Edisi Revisi). Jakarta: Rineka Cipta.

Nugroho, T. \& Utama, B. I. (2014). Masalah kesehatan reproduksi wanita (Cetakan 1). Yogyakarta: Nuha Medika.

Pudiastuti, R. D. (2011). Buku ajar kebidanan komunitas (Cetakan 1). Yogyakarta: Nuha Medika.

Reis, N., Bebis, H., Kose, S., Sis, A., Engin, R., \& Yavan, T. (2012). Knowledge, behavior, and beliefs for cervical cancer and screening among Turkish women.. Asian Pac J Cancer Prev, 13(4): 14631470.

Saydam, S. G. (2012). Waspadai penyakit reproduksi Anda (Cetakan 1). Jakarta: Pustaka Reka Cipta. 